\title{
The effect of low dose sildenafil on verapamil - induced cardiovascular toxicity in rats
}

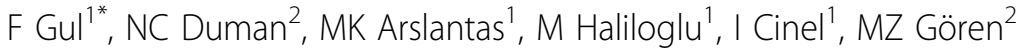 \\ From ESICM LIVES 2015 \\ Berlin, Germany. 3-7 October 2015
}

\section{Introduction}

Experimental studies have shown that sildenafil, a phosphodiesterase type 5 inhibitor, may have significant cardioprotective effects if used in low doses [1,2].

\section{Objectives}

The aim of this study was to compare the efficacies of glucagon and sildenafil treatments in anesthetized rats receiving verapamil overdose.

\section{Methods}

Male Sprague-Dawley rats ( $\mathrm{n}=8$ per group), weighing 300-350 g were used in the study. The iliac arteries and veins of rats bilaterally were catheterized under urethane anaesthesia. Upon completion of catheterization, the rats were connected to a monitor to observe blood pressure and heart rate throughout the procedures. Toxicity was induced by infusion of verapamil $15 \mathrm{mg} / \mathrm{kg}$ until 10 minutes. The rats received either continuous infusion of sildenafil $(0.06 \mathrm{mg} / \mathrm{kg} / \mathrm{h})$, glucagon $(2 \mathrm{mg} / \mathrm{kg} / \mathrm{h})$ or $0.3 \mathrm{mcg} / \mathrm{kg} / \mathrm{min}$ noradrenaline added to sildenafil $0.06 \mathrm{mg} / \mathrm{kg} / \mathrm{h}$ infusion. A naive controls and saline treated control experiments were also done. The rats were sacrificed by cervical dislocation at $60 \mathrm{~min}$. In order to make an integrative comparison, the area under curve in the pressure vs time plot of each rat was calculated. One-way analysis of variance was used followed by Tukey's test for statistical analysis.

\section{Results}

Verapamil infusion produced decreases in the mean arterial pressure values (MAP). The $\mathrm{AUC}_{10-60 \mathrm{~min}}$ of MAP plot was significantly lower in the control group, and both treatments produced significant increases in

${ }^{1}$ Marmara University, Department of Anaesthesiology, Division of Intensive Care Unit, Istanbul, Turkey

Full list of author information is available at the end of the article

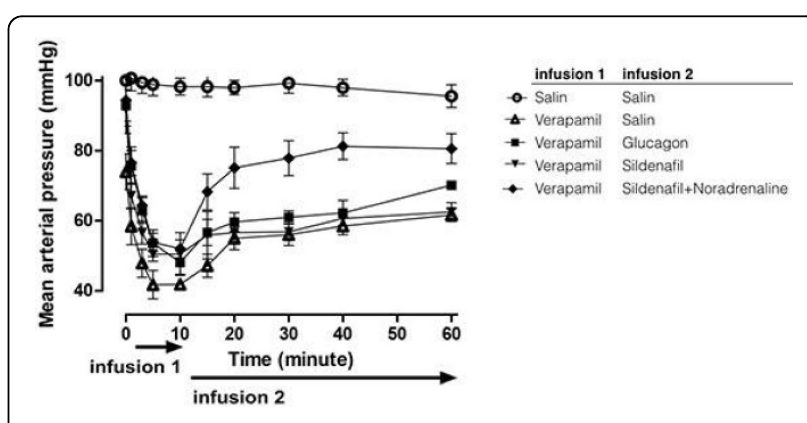

Figure 1 The MAP (mean $\pm S D$ ) of the rats during verapamil intoxication according to treatment groups.

the $\mathrm{AUC}_{10-60}$ min of MAP plots $(\mathrm{p}<0.05)$. Noradrenaline added to the sildenafil infusion was found to generate better values in the cardiovascular parameters $(\mathrm{p}<0.01)$.

Comparison of pulse pressure did not yield a significant difference. Heart rate values were restored better in the group that received noradrenaline adjunct.

\section{Conclusions}

The results of this study may imply that sildenafil alone is no better than glucagon, the classical treatment approach in verapamil toxicity. However, sildenafil may be more effective if used with a vasopressor adjunct.

\section{Authors' details \\ ${ }^{1}$ Marmara University, Department of Anaesthesiology, Division of Intensive Care Unit, Istanbul, Turkey. ${ }^{2}$ Marmara University, Department of Medical Pharmacology, Istanbul, Turkey. \\ Published: 1 October 2015 \\ References \\ 1. Elrod JW, Greer JJ, Lefer DJ: Sildenafil-mediated acute cardioprotection is independent of the NO/cGMP pathway. Am J Physiol Heart Circ Physiol 2007, 292(1):342-347. \\ 2. Kolettis TM, Kontaras K, Spartinos I, Maniotis C, Varnavas V, Koutouzis M, et al: Dose-dependent effects of sildenafil on post-ischaemic left}


doi:10.1186/2197-425X-3-S1-A500

Cite this article as: Gul et al:: The effect of low dose sildenafil on

verapamil - induced cardiovascular toxicity in rats. Intensive Care

Medicine Experimental 2015 3(Suppl 1):A500.

\section{Submit your manuscript to a SpringerOpen ${ }^{\circ}$ journal and benefit from:}

- Convenient online submission

- Rigorous peer review

- Immediate publication on acceptance

- Open access: articles freely available online

- High visibility within the field

- Retaining the copyright to your article

Submit your next manuscript at $\gg$ springeropen.com 